\title{
IMPLIKASI HUKUM DAN LEGALITAS TAX AMNESTY TERHADAP TINGKAT KEPATUHAN WAJIB PAJAK DI INDONESIA
}

Kajian Putusan Mahkamah Konstitusi Nomor 63/PUU-XIV/2016

\section{THE IMPLICATION AND LEGALITY OF TAX AMNESTY ON TAXPAYERS' COMPLIANCE IN INDONESIA}

\author{
An Analysis of Constitutional Court Decision Number 63/PUU-XIV/2016
}

\author{
Agnes Harvelian \\ Faculty of Law, Far Eastern Federal University \\ Vladivostok, Rusia \\ E-mail: agnesharvelian@gmail.com
}

Naskah diterima: 3 Juli 2017; revisi: 13 November 2017; disetujui 18 Desember 2017

http://dx.doi.org/10.29123/jy.v10i3.174

\begin{abstract}
ABSTRAK
Undang-Undang Nomor 11 Tahun 2016 tentang Pengampunan Pajak merupakan sebuah regulasi dari pemerintah sebagai bagian dari peningkatan penerimaan pajak di Indonesia. Pengampunan pajak dinilai memiliki berbagai kekurangan yang mencederai nilai keadilan dan konstitusionalitas. Pengujian undang-undang yang telah diputus oleh Mahkamah Kontitusi dengan Putusan Nomor 63/PUU-XIV/2016 dan memperkuat undangundang a quo untuk tetap berlaku di Indonesia. Putusan ini dinilai tidak sejalan dengan fakta sosial dan hukum yang terjadi di masyarakat. Penelitian ini bermaksud untuk menjawab dan menganalisis bagaimanakah pertimbangan Mahkamah Konstitusi terhadap pengujian Undang-Undang Pengampunan Pajak serta menganalisis bagaimana implikasi hukum setelah putusan Mahkamah Konstitusi. Metode pendekatan yang digunakan dalam penelitian ini adalah deskriptif analisis yang menjelaskan dan menganalisis peraturan hukum sebagai peraturan yang dibuat oleh pemerintah Indonesia, dan pertimbangan Mahkamah Konstitusi terhadap permohonan pengujian undang-undang, yang dihubungkan dengan implikasi hukum pengampunan pajak setelah putusan Mahkamah
\end{abstract}

Konstitusi. Putusan Nomor 63/PUU-XIV/2016 menjadi dasar dari berlakunya pengampunan pajak saat ini dan menjadi referensi di masa yang akan datang. Mahkamah Konstitusi menyatakan bahwa undang-undang ini tidak bertentangan dengan UUD NRI 1945. Keberhasilan undang-undang ini tidaklah sempurna, karena terdapat satu unsur penerimaan tax amnesty yakni repatriasi yang berdampak pada peningkatan subjek dan objek pajak baru tidak terpenuhi.

Kata kunci: pengampunan pajak, putusan Mahkamah Konstitusi, kepatuhan wajib pajak.

\section{ABSTRACT}

Law Number 11 of 2016 on Tax Amnesty is a regulation set by the government as part of an enhancement in tax revenues in Indonesia. The tax amnesty has various drawbacks which has damaged justice value and constitutionality. The judicial review on tax amnesty law has been decided by the Constitutional Court with Court Decision Number 63/PUU-XIV/2016 and it strengthen the a quo law to remain in force in Indonesia. This decision is considered inconsistent with the social and legal facts that occur in society. This analysis intends to answer 
and examine how the consideration of the Constitutional Court on the judicial review to Tax Amnesty Law and analyze how the legal implications after the issuance of the Constitutional Court Decision. The method used in this analysis is descriptive analytic describing and analyzing the statutory regulations as stipulated by the Indonesian Government, and legal consideration of the Constitutional Court regarding the petition for judicial review, which is related to the legal implications of tax amnesty after the decision of the Constitutional Court.

\section{PENDAHULUAN}

\section{A. Latar Belakang}

Berlakunya Undang-Undang Nomor 11 Tahun 2016 tentang Pengampunan Pajak merupakan sebuah regulasi yang tidak lagi menjadi hal baru di Indonesia. Dalam sejarahnya, Indonesia telah memiliki kebijakan pengampunan pajak atau lebih sering disebut sebagai tax amnesty sebanyak tiga kali, yakni tahun 1964, 1984, dan 2008.

Program pengampunan pajak tahun 1964 diatur oleh Penetapan Presiden Nomor 5 Tahun 1964 tentang Peraturan Pengampunan Pajak. Tahun 1984, didasarkan dengan Keputusan Presiden Nomor 26 Tahun 1984 dan kemudian di tahun 2008, penamaan berubah menjadi sunset policy yang didasari pada Pasal 37A UndangUndang Nomor 28 Tahun 2007 tentang Ketentuan Umum dan Tata Cara Perpajakan. Meski telah diatur jelas dalam Undang-Undang Ketentuan Umum dan Tata Cara Perpajakan, program ini juga diperkuat melalui Peraturan Menteri Keuangan Nomor 18/PMK.03/2008.

Kebijakan pengampunan pajak tahun 2016 mendapatkan perhatian serius dari masyarakat, badan hukum, dan berbagai negara yang menjadi tempat penyimpanan aset kekayaan warga negara
The Constitutional Court Decision Number 63/PUUXIV/2016 becomes the basis of current tax amnesty and a reference in the forthcoming. This legislation is not contradictory to the 1945 Constitution. The realization of this legislation is not impeccable, because there is one element of acceptance of the tax amnesty, precisely repatriation that impact on the increase of unfulfilled subject and object of new tax.

Keywords: tax amnesty, Constitutional Court Decision, tax compliance.

Indonesia. Hal ini ditengarai bukan hanya pada segmentasi target yang lebih luas, melainkan juga disebabkan bentuk hukum pengaturannya jauh lebih kuat jika dibandingkan program pengampunanpajaksebelumnya,karenakebijakan pengampunan pajak tahun 2016 langsung dimuat dalam undang-undang. Artinya secara hukum terjadi penguatan dari aspek bentuk atau dasar hukum yang digunakan dalam menjalankan program ini (Isra, 2016: 251). Sebelum lahirnya Undang-Undang Nomor 11 Tahun 2016 tentang Pengampunan Pajak sebagai dasar pemberlakuan berjalannya kebijakan pengampunan pajak tahun 2016, lebih dulu kebijakan ini didahului oleh Tahun Pembinaan Wajib Pajak 2015. Kebijakan Tahun Pembinaan Wajib Pajak didasari pada Pasal 36 ayat (1) huruf a Undang-Undang Ketentuan Umum dan Tata Cara Perpajakan, yang diperkuat dengan Peraturan Menteri Keuangan Nomor 91/ PMK.03/2015 serta Peraturan Menteri Keuangan Nomor 29/PMK.03/2015.

Berbagai strategi kebijakan perpajakan yang dilakukan oleh pemerintah didasari atas tingkat pertumbuhan ekonomi Indonesia yang belum sejalan dengan berbagai agenda pembangunan dan pemenuhan kebutuhan investasi di berbagai sektor. Tidak hanya di Indonesia, yang menjadikan pajak sebagai sumber pembiayaan 
terbesar pembangunan, di berbagai negara juga melakukan hal sama, penerimaan pajak menjadi tumpuan pembangunan (Luitel, 2014: 1).

Pendapatan negara tahun 2014 mencapai 1.537,2 triliun atau 94\% dari rencana dalam APBN-P sebesar 1.246,1 triliun dan penerimaan pajak menyumbang angka 1.143,3 triliun atau $91,7 \%$ dari target sebesar 1.246,1 triliun. Pendapatan negara tahun 2015 sebesar 1.492,5 triliun atau 84,7\% dari APBN-P sebesar 1.761,6 triliun dengan penerimaan pajak mencapai 1.235,8 triliun atau 83\% dari APBN-P 1.489,3 triliun (Kemenkeu, tt). Pendapatan negara tahun 2016 $1.551,8$ triliun hanya $86,9 \%$ dari target APBN-P sebesar 1.786,2 triliun dengan penerimaan pajak mencapai $1.104,9$ triliun hanya $81,5 \%$ dari target $1.355,2$ triliun.

Pendapatan negara masih bergatung pada sektor penerimaan pajak, kendati demikian realisasi penerimaan pajak masih belum sesuai dengan target dan kebutuhan belanja negara. Dalam kurun waktu 10 tahun terakhir realisasi penerimaan pajak selalu di bawah target (kecuali tahun 2008) dengan pencapaian tax ratio 11-13\% (Inside Tax, 2016: 34-35). Tax ratio digunakan untuk mengukur perbandingan antara penerimaan pajak dengan Gross Domestic Product (GDP) suatu negara.

Bahkan di awal tahun 2017, Menteri Keuangan Republik Indonesia merilis tax ratio Indonesia di bawah 11\% dan menjadi angka terendah di dunia. Berdasarkan data yang dipublikasi oleh Heritage Foundation yang berbasis di Washington DC, Amerika Serikat. Tax ratio Denmark mencapai 50.9\%, Perancis 45.2\%, Brunei Darusallam 33.1\%, Australia 27.5\%, Papua New Guinea 23.5\%, Vietnam 18.2\%, dan Malaysia 14.8\%.
Rendahnya tax ratio Indonesia dipengaruhi oleh tingkat kepatuhan wajib pajak yang masih kurang. Pada tahun 2015, wajib pajak yang terdaftar mencapai 30.044.103 wajib pajak. Menurut data Badan Pusat Statistik, hingga tahun 2013 jumlah penduduk Indonesia yang bekerja mencapai 93,72 juta orang. Artinya, baru sekitar $29,4 \%$ dari total jumlah orang pribadi pekerja dan berpenghasilan di Indonesia yang mendaftarkan diri atau terdaftar sebagai wajib pajak (Dirjen Pajak, 2016).

Salah satu faktor yang berpengaruh terhadap rendahnya kepatuhan wajib pajak ditengarai pada sebuah kondisi individu atau badan yang mempunyai kekayaan yang berasal dari penghindaran atau penggelapan pajak, mereka akan melakukan segala upaya untuk menyembunyikan atau menyimpan kekayaan tersebut baik di dalam atau di luar negeri.

Munculnya kebijakan pengampunan pajak melalui Undang-Undang Nomor 11 Tahun 2016 tentang Pengampunan Pajak diharapkan dapat meningkatkan subjek pajak maupun objek pajak. Subjek pajak dapat berupa kembalinya dana-dana yang berada di luar negeri, sedangkan dari sisi objek pajak berupa penambahan jumlah wajib pajak (DPR RI, 2016).

Undang-Undang Nomor 11 Tahun 2016 tentang Pengampunan Pajak di uji materiil ke Mahkamah Konstitusi. Terdapat empat permohonan uji materi terhadap undang-undang tersebut. Mereka adalah Serikat Perjuangan Rakyat Indonesia, Yayasan Satu Keadilan, Dewan Pengurus Pusat Serikat Buruh Sejahtera Indonesia, Konfederasi Serikat Pekerja Indonesia, Konfederasi Serikat Pekerja Seluruh Indonesia, dan seorang warga bernama Leni Indrawati. Adapun empat perkara itu teregistrasi dengan 
Nomor 57/PUU-XIV/2016, 58/PUU-XIV/2016, 59/PUU-XIV/2016, dan 63/PUU-XIV/2016.

Para pemohon mengajukan permohonan uji materiil yaitu, Pasal 1 angka 1; Pasal 3 ayat (1), ayat (2), ayat (3), ayat (4) dan ayat (5); Pasal 4 ayat (1), ayat (2), dan ayat (3); Pasal 21 ayat (2) dan ayat (3); Pasal 22; dan Pasal 23 ayat (1) dan ayat (2) Undang-Undang Nomor 11 Tahun 2016 tentang Pengampunan Pajak terhadap Pasal 1 ayat (3), Pasal 23A, Pasal 27 ayat (1), dan Pasal 28F UUD NRI 1945.

Para pemohon mendalilkan bahwa pajak sebagai setoran wajib pada kas negara yang dapat dipaksakan telah dijalankan secara patuh oleh para buruh/pekerja/karyawan (berasal dari pegawai negeri sipil dan swasta) setiap bulannya. Pajak merupakan suatu beban bagi para wajib pajak, yang dibayarkan tanpa mendapat jasa timbal balik secara langsung. Pengaturan tentang pajak telah diatur di dalam UUD NRI 1945, kewajiban para wajib pajak membayar pajak akan melahirkan hak konstitusional untuk seluruh wajib pajak yang telah menunaikan kewajibannya untuk mendapatkan kesejahteraan.

Pajak penghasilan menyumbang 70-75\% pendapatan negara. Kesadaran dan kesukarelaan membayar pajak secara sadar telah mengurangi berbagai kebutuhan hidup yang harusnya terpenuhi oleh para wajib pajak namun harus dikesampingkan untuk membayar pajak. Hak kesejahteraan yang harusnya didapat oleh seluruh wajib pajak yang patuh dan taat juga tercederai oleh para warga negara yang melakukan kejahatan pajak dan tidak membayar pajak.

\section{Disahkannya}

Undang-Undang

Pengampunan Pajak, dinilai mencederai rasa keadilan dan menjadi legitimasi untuk memaafkan para pengemplang pajak. Wajib pajak yang tidak patuh atau secara sadar dan sengaja tidak termasuk ke dalam objek pajak, menjadi penghalang pemerintah menciptakan kesejahteraan bagi rakyat. Penghambatan ini berdampak pada tidak terpenuhinya hak-hak konstitusional yang seharusnya didapat oleh para wajib pajak. Pada 14 Desember 2016, Mahkamah Konstitusi memutuskan bahwa pokok permohonan tidak dapat diterima. Putusan ini menjadi dasar berlakunya kebijakan pengampunan pajak yang dinilai mencederai rasa keadilan dan menjadi legitimasi perilaku jahat para masyarakat yang tidak patuh membayar pajak.

Terdapat tujuh alasan yang menjadi pertimbangan Mahkamah Konstitusi dalam memutus Putusan Nomor 63/PUU-XIV/2016. Keadaan ekonomi di tahun 2008 yang masih belum pulih sepenuhnya menjadi pertimbangan. Mahkamah Konstitusi mempertimbangkan bahwa pemberlakuan undang-undang pengampunan pajak di kemudian hari akan memberi keadilan kepada masyarakat dengan dimilikinya data baru terkait wajib pajak. Putusan ini menimbulkan berbagai polemik, tujuan untuk merepatriasi dana di luar negeri, meningkatkan basis perpajakan nasional, dan untuk meningkatkan penerimaan pajak tidak serta merta menjadi alasan pembenar untuk setiap kali menjalankan kebijakan pengampunan pajak.

\section{Pertimbangan Mahkamah Konstitusi} dipenuhi dengan berbagai alasan teknis terkait Undang-Undang Pengampunan Pajak. Mendapat keuntungan sebanyak-banyaknya menjadi dasar dari pemberlakuan kebijakan ini. Pemaknaan reformasi pajak yang berkelanjutan tidak menjadi muatan yang nyata dalam pertimbangan tersebut. Kebijakan pengampunan pajak bukan sesuatu yang baru, jika kebijakan ini secara berkala terus dilakukan, seharusnya Mahkamah Konstitusi 
dapat menganalisis bahwa tujuan hakiki dari pengampunan pajak selama ini belum tercapai. Berakhirnya pengampunan pajak 31 Maret 2017, memberi catatan keberhasilan pada sisi deklarasi pajak sebesar 4.600 triliun melebih target sebesar 4.000 triliun. Namun, pada repatriasi hanya mencapai 147 triliun dari target 1.000 triliun.

\section{B. Rumusan Masalah}

Berdasarkan latar belakang di atas, rumusan masalah yang diangkat dalam kajian ini adalah:

1, Bagaimanakah pertimbangan hukum Mahkamah Konstitusi yang menolak pengujian Undang-Undang Pengampunan Pajak dalam Putusan Nomor 63/PUU$\mathrm{XIV} / 2016 ?$

2, Bagaimanakah implikasi hukum dan legalitas hukum amnesti pajak terhadap tingkat kepatuhan wajib pajak di Indonesia?

\section{C, Tujuan dan Kegunaan}

Tujuan penelitian ini adalah untuk mengetahui dan menganalisis dasar pertimbangan Mahkamah Konstitusi dalam memutuskan pokok permohonan tidak dapat diterima dalam Putusan Nomor 63/PUU-XIV/2016; dan mengetahui implikasi dan legalitas hukum atas Putusan Nomor 63/PUU-XIV/2016 terhadap tingkat kepatuhan wajib pajak.

Kegunaan atau manfaat yang diharapkan tercapai dari penelitian ini adalah secara teoritis diharapkan dapat memberikan sumbangan pengetahuan mengenai implikasi dan legalitas tax amnesty terhadap tingkat kepatuhan wajib pajak di indonesia. Secara praktis diharapkan dapat mengevaluasi kebijakan pengampunan pajak berdasarkan Undang-Undang Nomor 11
Tahun 2016 tentang Pengampunan Pajak sebagai pertimbangan jangka panjang.

D. Tinjauan Pustaka

\section{Pengertian Pengampunan Pajak atau Tax Amnesty}

Berdasarkan Pasal 1 angka 1 UndangUndang Nomor 11 Tahun 2016 tentang Pengampunan Pajak, tertulis bahwa:

Pengampunan pajak adalah penghapusan pajak yang seharusnya terutang, tidak dikenai sanksi administrasi perpajakan dan sanksi pidana di bidang perpajakan, dengan cara mengungkap harta dan membayar uang tebusan sebagaimana diatur dalam undang-undang ini.

Secara lebih luas pajak mempunyai dua fungsi utama, yaitu: fungsi penerimaan (budgetair) dan fungsi mengatur (reguler). Fungsi budgetair dimaksudkan bahwa pajak berfungsi sebagai sumber dana yang diperuntukkan bagi pembiayaan pengeluaran pemerintah. Sedangkan fungsi reguler dimaksudkan sebagai alat untuk mengatur atau melaksanakan kebijakan di bidang sosial ekonomi.

Aturan tentang perpajakan di Indonesia terdapat dalam Pasal 23A UUD NRI 1945. Lebih lanjut bahwa pengampunan pajak sering kali dijadikan alat untuk menghimpun penerimaan negara dari sektor pajak (tax revenue) secara cepat dalam jangka waktu yang relatif singkat (DPR RI, 2016: 38). Hal ini terjadi dikarenakan rendahnya tingkat kepatuhan wajib pajak, yang menghindari pembayaran pajak.

Sumitro menegaskan bahwa pajak adalah iuran rakyat kepada kas negara, dapat dipaksakan dengan tiada mendapat jasa timbal balik yang langsung dapat ditunjukkan dan digunakan untuk membiayai pengeluaran umum (Mardiasmo, 
2011: 1). Pengampunan pajak menjadi salah satu cara untuk memperoleh pajak dari para warga negara Indonesia yang memiliki dana di luar negeri dan atau dalam negeri yang sengaja tidak melaporkannya.

\section{Penafsiran Hukum dan Konstitusi oleh Hakim}

Proses penafsiran hukum merupakan prasyarat, tahap awal pelaksanaan norma-norma hukum. Menurut Trubetskoy seorang filsuf hukum asal Rusia, penafsiran hukum diperlukan untuk membentuk makna yang tepat dalam ketentuan hukum. Mencari tahu esensi dari maksud dan tujuan hukum adalah fungsi dari penafsiran hukum.

Interpretasi di dalam konstitusi menjadi penting dalam pelaksanaan hak dalam menjamin perwujudan prinsip UUD NRI 1945 dalam praktik sosial. UUD NRI 1945 memberi hak kepada Mahkamah Konstitusi sebagai penafsir undangundang dasar. Ini merupakan hak prerogratif Mahkamah Konstitusi untuk menafsirkan kehendak rakyat dalam UUD NRI 1945. Tidak ada otoritas publik lainnya yang dapat menafsirkan resmi konstitusi, karena penafsiran konstitusi hanya melalui proses konstitusional.

Tujuan dari penafsiran konstitusi adalah untuk mengatasi ketidakpastian dalam memahami ketentuan konstitusional. Penafsiran konstitusi dibutuhkan dalam menjelaskan berbagai ketentuan yang terkandung di dalamnya, karena pemahaman yang tidak merata pada normanorma konstitusi dan perbedaan pemahaman dalam terminologi. Konstitusi merupakan hukum dasar tertinggi, di mana semua elemen saling terkait dan terkoordinasi. Oleh karena itu, ketentuan konstitusi harus ditafsirkan sebagai bagian dari sistem terpadu dari hukum konstitusi untuk menghindari inkonsistensi dan kontradiksi dari ketentuan dalam UUD NRI 1945.

Terdapat lima jenis metode penafsiran, antara lain: penafsiran menurut asal kata, penafsiran historis, penafsiran sistematis, penafsiran sosiologis, dan penafsiran autentik (Asshidiqie, 2010: 224-226).

\section{Kepatuhan Wajib Pajak}

Menurut Sidik, kepatuhan memenuhi kewajiban perpajakan secara sukarela merupakan tulang punggung sistem self assestment system, di mana wajib pajak bertanggung jawab menetapkan sendiri kewajiban perpajakan dan kemudian secara akurat dan tepat waktu membayar dan melaporkan pajaknya tersebut (Rahayu, 2010: 137-138).

Menurut kamus umum bahasa Indonesia, patuh berarti tunduk atau patuh pada aturan. Dalam hal perpajakan diartikan patuh terhadap aturan perpajakan. Menurut Nasucha, kepatuhan wajib pajak dapat diidentifikasi dari:

a. Kepatuhan wajib pajak dalam mendaftarkan diri

b. Kepatuhan untuk melaporkan kembali surat pemberitahuan

c. Kepatuhan dalam penghitungan dan pembayaran pajak terutang; dan

d. Kepatuhan dalam pembayaran tunggakan (Rahayu, 2010: 139).

Rahayu (2010), kepatuhan perpajakan dapat didefinisikan sebagai "suatu keadaan di mana wajib pajak memenuhi semua kewajiban perpajakan dan melaksanakan hak 
perpajakannya." Terdapat dua macam kepatuhan pajak, yaitu kepatuhan formal dan kepatuhan material. Kepatuhan formal adalah suatu keadaan di mana wajib pajak dapat memenuhi kewajiban perpajakan secara formal dengan ketentuan yang ada di dalam undang-undang perpajakan. Kepatuhan material adalah suatu keadaan di mana wajib pajak secara substantif sudah memenuhi semua ketentuan material perpajakan, yakni sesuai isi dan jiwa undang-undang perpajakan.

Namun demikian, dilansir dalam laporan Direktorat Jenderal Pajak Kementrian Keuangan, kepatuhan wajib pajak belum mencapai tingkat yang diharapkan. Dari data yang diperoleh dari laporan tahunan tahun 2014, dari jumlah wajib pajak terdaftar sebesar 30.574.428 hanya 58,87\% yang menyampaikan SPT Tahunan PPh-nya. Angka tersebut adalah data dari kepatuhan formal. Sedangkan kepatuhan secara material masih sulit untuk diukur karena keterbatasan sarana dan data pembanding yang akurat.

Dari hasil studi yang dilakukan oleh World Bank dan Price Water House Coopers dan hasilnya dirilis dalam sebuah buku berjudul "Paying Taxes 2016," disebutkan bahwa kunci kepatuhan wajib pajak adalah kemudahan dalam membayar pajak. Artinya reformasi perpajakan di Indonesia harus diikuti dengan pembenahan sistem pembayaran pajak, yang memudahkan setiap wajib pajak untuk melaksanakan kewajibannya.

\section{METODE}

Penelitian ini menggunakan metode penelitian hukum yuridis normatif (Soekanto \& Mamuji, 2006: 15). Data yang ada dihubungkan satu sama lain melalui studi kepustakaan (library research), dikaji, diinterpretasikan, dan dianalisis untuk selanjutnya ditarik kesimpulannya. Metode penelitian yuridis normatif adalah penelitian yang mengacu kepada norma-norma hukum yang terdapat dalam peraturan perundang-undangan, konvensi internasional, perjanjian internasional, dan putusan-putusan pengadilan (Hartono, 1994: 143). Di mana sumber datanya diperoleh dari bahan kepustakaan atau data sekunder (Amiruddin \& Asikin, 2012: 118) yang terdiri dari bahan hukum primer, antara lain norma atau kaidah dasar, yaitu pembukaan UUD NRI 1945 dan peraturan perundang-undangan. Sedangkan bahan hukum sekunder, antara lain buku-buku, hasil penelitian, serta pendapat pakar hukum. Data yang diperoleh akan dianalisis dengan metode deskriptif kualitatif.

\section{HASIL DAN PEMBAHASAN}

\section{A. Pertimbangan Hukum Mahkamah Konstitusi terhadap Undang-Undang Pengampunan Pajak}

Diundangkannya Undang-Undang

Nomor 11 Tahun 2016 tentang Pengampunan Pajak dijawab oleh masyarakat terkait dengan diajukannya permohonan uji materiil kepada Mahkamah Konstitusi. Undang-undang ini dinilai mencederai rasa keadilan yang dilakukan pemerintah kepada warga negara Indonesia yang taat membayar pajak dengan mereka yang justru tidak taat membayar pajak.

Undang-undang a quo terdiri dari $13 \mathrm{bab}$ dan 25 pasal, dan terdapat 6 pasal yang diajukan permohonan uji materiil kepada Mahkamah Konstitusi. Pada tanggal 28 Juli 2016 berdasarkan akta penerimaan berkas permohonan Nomor 129/PAN.MK/VII/2016 dan telah dicatat dalam buku registrasi perkara konstitusi pada tanggal 25 Agustus 2016 dengan Nomor 63/PUU- 
XIV/2016, yang telah diperbaiki dan diterima Kepaniteraan Mahkamah Konstitusi pada tanggal 13 September 2016.

Para pemohon mengajukan permohonan uji materiil yaitu: Pasal 1 angka 1; Pasal 3 ayat (1), ayat (2), ayat (3), ayat (4), dan ayat (5); Pasal 4 ayat (1), ayat (2), dan ayat (3); Pasal 21 ayat (2) dan ayat (3); Pasal 22; dan Pasal 23 ayat (1) dan ayat (2) Undang-Undang Nomor 11 Tahun 2016 tentang Pengampunan Pajak terhadap Pasal 1 ayat (3), Pasal 23A, Pasal 27 ayat (1), dan Pasal 28F UUD NRI 1945.

Alasan hukum yang dikemukakan oleh pemohon atas enam pasal yang diuji materiilkan antara lain:

\section{Pasal 1 angka 1}

Pasal ini merupakan ketentuan dasar dari Undang-Undang Pengampunan Pajak, yang memuat dalil tentang:

"Pengampunan pajak adalah penghapusan pajak yang seharusnya terhutang, tidak dikenai sanksi administrasi perpajakan dan sanksi pidana di bidang perpajakan, dengan cara mengungkap harta dan membayar uang tebusan sebagaimana diatur dalam undang-undang ini."

Pasal ini dinilai bertentangan dengan Pasal 1 ayat (3) dan 23A UUD NRI 1945. Dalam Pasal 1 ayat (3) tertulis negara Indonesia adalah negara hukum. Pasal 23A tertulis pajak dan pungutan lain yang bersifat memaksa untuk keperluan negara diatur dengan undang-undang. Ketentuan ini bertentangan dengan Pasal 1 ayat (3) UUD NRI 1945 dikarenakan sebagaimana yang dimaksud dalam Pasal 1 angka 1 UndangUndang Pengampunan Pajak, bahwa terdapat penghapusan sanksi administrasi dan pidana kepada setiap wajib pajak yang tidak patuh membayar pajak. Kebijakan ini menjadi esensi dari makna pengampunan pajak, yang kemudian secara bersamaan dinilai melanggar Pasal 23A UUD NRI 1945.

2. Pasal 3 ayat (1), ayat (2), ayat (3), ayat (4), dan ayat (5)

Pasal 3 termasuk ke dalam bab tentang subjek dan objek pengampunan pajak. Pada ketentuan ini, pemohon menilai bahwa pasal ini bertentangan dengan prinsip Indonesia sebagai negara hukum, dan kemudian melanggar Pasal 27 ayat (1) UUD NRI 1945. Setiap warga negara memiliki kedudukan yang sama di depan hukum, terlebih di dalam ketentuan Pasal 3 ayat (3) huruf a, yang tertulis:

"Dikecualikan dari ketentuan sebagaimana dimaksud pada ayat (1), yaitu wajib pajak yang sedang:

a. Dilakukan penyidikan dan berkas penyidikannya telah dinyatakan lengkap oleh kejaksaan."

Bagaimana mungkin harus dipersyaratkan dengan berkas telah dinyatakan lengkap oleh kejaksaan, hal ini tentu akan membebaskan wajib pajak yang dinyatakan belum lengkap oleh kejaksaan, padahal sedang berlangsung proses hukum di tahap penyidikan. Hal ini akan melanggar prinsip negara hukum dan persamaan di muka hukum.

3. Pasal 4 ayat (1), ayat (2), dan ayat (3)

Terdapat pada Bab IV tentang Tarif dan Cara Menghitung Uang Tebusan, pemohon mendalilkan kerugian yang nampak jelas dalam pasal tersebut. Besaran pajak yang dibebankan kepada setiap wajib pajak yang mengikuti program pengampunan pajak dinilai tidak adil. Nilainya tidak sesuai dengan para wajib pajak yang telah patuh membayar pajak secara berkala. 
Besaran pajak yang dibebankan untuk deklarasi harta di kisaran angka 2-5\% dan untuk tarif tebusan deklarasi aset yang tetap ditaruh di luar negeri besarnya $4-10 \%$, tergantung pada waktu kapan seorang wajib pajak mendaftarkannya. Sedangkan tarif pajak bagi setiap wajib pajak dengan peredaran usaha sampai dengan 4.8 miliar dikenakan $0,5-2 \%$.

Hal ini dinilai sangat jauh dari rasa keadilan, sebagaimana yang tertulis dalam Undang-Undang Nomor 28 Tahun 2007 tentang Perubahan Ketiga atas Undang-Undang Nomor 6 Tahun 1983 tentang Ketentuan Umum dan Tata Cara Perpajakan, besaran yang ditentukan dalam Undang-Undang Pengampunan Pajak tidaklah sama dari biasanya dan mencederai keadilan bagi para pembayar pajak yang telah membayarkan pajaknya secara berkala tanpa melanggar aturan.

4. $\quad$ Pasal 21 ayat (2), dan ayat (3); Pasal 22; dan Pasal 23 ayat (1) dan ayat (2)

Ketiga pasal ini berisi ketentuan dalam kerahasian informasi, bahwa tidak seorangpun pejabat yang berwenang yang dapat membocorkan informasi para wajib pajak. Kemudian ketentuan pidana terdapat pada Pasal 23. Ketentuan ini dinilai telah melanggar Pasal 28F UUD NRI 1945 tentang hak asasi manusia, yaitu:

"Setiap orang berhak untuk berkomunikasi dan memperoleh informasi untuk mengembangkan pribadi dan lingkungan sosialnya, serta berhak untuk mencari, memperoleh, memiliki, menyimpan, mengolah, dan menyampaikan informasi dengan menggunakan segala jenis saluran yang tersedia."

Dengan diaturnya Pasal 21 dalam Undang-Undang Pengampunan Pajak, para pemohon menilai ketentuan ini telah melanggar hak konstitusional setiap warga negara untuk mengakses informasi dan tidak sesuai dengan prinsip keterbukaan informasi. Dampak yang terjadi atas ketentuan ini adalah rendahnya tingkat pengawasan publik kepada penyelenggaraan perpajakan di Indonesia.

Pengampunan pajak atau tax amnesty dinilai oleh para pemohon sebagai legitimasi atas perbuatan jahat dan membenarkan iktikad tidak baik dari para wajib pajak yang tidak patuh membayar karena berbagai alasan. Pajak yang seharusnya bersifat wajib bagi para warga negara yang telah tergolong sebagai wajib pajak dan harus dibayarkan secara berkala, serta memiliki sifat memaksa dinilai menjadi berbeda makna dengan munculnya Undang-Undang Pengampunan Pajak.

Terdapat ribuan triliun rupiah dana warga negara Indonesia yang disimpan di luar negeri dan bersumber dari berbagai kegiatan usaha. Berbagai motif untuk menutupi harta dan menghilangkan jejak penghasilan agar tidak perlu membayar pajak menjadi masalah turun temurun dari agenda reformasi pajak Indonesia. Namun menurut Prastowo (2016: 17), repatriasi aset yang diharapkan dari kebijakan tax amnesty belum tentu bisa terwujud karena faktanya beberapa aset tersebut sudah ada di Indonesia melalui skema pinjaman ke luar negeri.

Menghindari membayar pajak tidak serta merta didasari hanya karena tidak ingin membayar pajak, namun juga menutupi kegiatan usaha yang melanggar ketentuan pidana. Sumber dana yang berasal dari tindak pidana pencucian uang, kemudian harta yang diperoleh dari hasil korupsi, prostitusi, dan lain sebagainya.

Undang-Undang Pengampunan Pajak berpotensi untuk merubah status harta kekayaan seseorang yang berasal dari tindak pidana 
kejahatan dengan melawan hukum, yang kemudian seolah-olah menjadi harta kekayaan yang bersih setelah melaporkan dan diampuni dalam hal perpajakan. Hal ini adalah dua bagian yang berbeda, yakni permasalahan terkait pajak dan juga pidana yang bukanlah menjadi kewenangan para pejabat pajak.

Namun demikian, prinsip kerahasiaan informasi yang terdapat pada Undang-Undang Pengampunan Pajak, menjadi kekuatan yang justru melindungi para pelapor pajak, yang harta kekayaannya berasal dari yang tersebut di atas dalam program pengampunan pajak. Pegawai pajak tidak bisa melaporkan tindak pidananya sekalipun mengetahui dengan jelas asal usul harta kekayaannya. Maka, menurut prinsip UndangUndang Pengampunan Pajak tentang kerahasiaan informasi, para pejabat pajak dan mereka yang terkait tidak bisa melaporkan para wajib pajak sekalipun benar adanya harta tersebut diperoleh dari kegiatan usaha yang ilegal.

Pemohon mendalilkan bahwa UndangUndang Pengampunan Pajak dengan pasal yang diuji materiilkan, secara sah dan meyakinkan tidak memiliki kekuatan hukum mengingat . Terdapat empat poin yang menjadi petitum dari para pemohon, antara lain:

a. Menyatakan dan mengabulkan permohonan para pemohon untuk seluruhnya;

b. Menyatakan Pasal 1 angka 1; Pasal 3 ayat (1), ayat (2), ayat (3), ayat (4), dan ayat (5); Pasal 4 ayat (1), ayat (2), dan ayat (3); Pasal 21 ayat (2) dan ayat (3); Pasal 22; dan Pasal 23 ayat (1) dan ayat (2) Undang-Undang Nomor 11 Tahun 2016 tentang Pengampunan Pajak bertentangan dengan Pasal 1 ayat (3), Pasal 23A, Pasal 27 ayat (1), dan Pasal 28F UUD NRI 1945;

c. Menyatakan Pasal 1 angka 1; Pasal 3 ayat (1), ayat (2), ayat (3), ayat (4), dan ayat (5); Pasal 4 ayat (1), ayat (2), dan ayat (3); Pasal 21 ayat (2) dan ayat (3); Pasal 22; dan Pasal 23 ayat (1) dan ayat (2) Undang-Undang Nomor 11 Tahun 2016 tentang Pengampunan Pajak tidak sah dan tidak mempunyai kekuatan hukum mengikat;

d. Memerintahkan pemuatan amar putusan ini dalam Berita Negara Republik Indonesia sebagaimana mestinya.

\section{Urgensi Pengampunan Pajak}

Dalam sejarah perpajakan di Indonesia, terdapat tiga pembabakan waktu atas implementasi kebijakan pengampunan pajak. Program pengampunan pajak tahun 1964 diatur oleh Penetapan Presiden Nomor 5 Tahun 1964 tentang Peraturan Pengampunan Pajak. Tahun 1984, didasarkan dengan Keputusan Presiden Nomor 26 Tahun 1984 dan kemudian di tahun 2008, penamaan berubah menjadi sunset policy yang didasari pada Pasal 37A Undang-Undang Ketentuan Umum dan Tata Cara Perpajakan. Meski telah diatur jelas dalam Undang-Undang Ketentuan Umum dan Tata Cara Perpajakan, program ini juga diperkuat melalui Peraturan Menteri Keuangan Nomor 18/PMK.03/2008.

Kebijakan pengampunan pajak yang berulang, walaupun muncul dengan berbagai nama. Hal ini kemudian menyebabkan moral hazard atau anomali psikologis dari wajib pajak dan membuat individu membandingkan serta 
mempertanyakan persepsi dari keadilan dan kesetaraan (Nar, 2015 dalam Setyaningsih, 2016). Secara umum memang kepatuhan pajak meningkat, namun hal ini tidak mencerminkan keadaan yang sebenarnya. Situasi menunjukkan bahwa aset ekonomis yang berasal dari pencucian uang dikembalikan dengan sistem yang legal.

Analisis tentang pengampunan pajak tidak bisa hanya mengetahui pengampunan pajak sebagai bagian dari kebijakan pemerintah. Akan tetapi, secara lebih komprehensif mengarah kepada ekonomi anggaran Indonesia. Tujuan besar dari pemberlakuan kebijakan pengampunan pajak diharapkan dapat meningkatkan subjek pajak maupun objek pajak. Subjek pajak dapat berupa kembalinya dana-dana yang berada di luar negeri, sedangkan dari sisi objek pajak berupa penambahan jumlah wajib pajak.

Pengampunan pajak merupakan salah satu metode untuk meningkatkan wajib pajak dengan menghapus sanksi administrasi maupun pidana sebagai bagian dari strategi penerimaan pajak dari para pengemplang pajak. Terdapat dua implikasi dari diberlakukannya pengampunan pajak, antara lain:

\section{a. Jangka Pendek}

Pengampunan pajak sebagai pilihan logis dari sebuah negara yang apabila diberlakukan akan menambah basis penerimaan pendapatan negara. Perolehan dana segar dari dampak pemberlakuan pengampunan pajak akan masuk ke dalam APBN. Kondisi ini dinilai sebagai implikasi jangka pendek dari kebijakan pengampunan pajak, yakni penambahan dana pada kas negara. b. Jangka Panjang

Secara makro sebetulnya
pemberlakuan pengampunan pajak harus menjadi salah satu agenda reformasi pajak di Indonesia. Tax ratio yang masih sangat rendah harus dijawab dengan reformasi perbaikan sistem demi meningkatkan kepatuhan wajib pajak secara berkala atau jangka panjang.

Implikasi jangka pendek merupakan sesuatu yang memang sudah seharusnya didapat oleh pemerintah sebagai akibat dari pemberlakuan pengampunan pajak. Namun demikian, impilkasi jangka panjang akan sangat sulit direalisasikan apabila tidak didampingi dengan pembenahan sistem dari perpajakan di Indonesia. Reformasi perpajakan dalam bidang hukum, menciptakan iklim perpajakan yang kondusif, dan mempersiapkan infrastruktur yang kuat. Ketiga hal ini menjadi faktor dari realisasi jangka panjang berlakunya pengampunan pajak, yang akan membuat kepercayaan, kesadaran, dan kepatuhan wajib pajak meningkat.

Terhitung sejak tahun 1945 Indonesia merdeka hingga saat ini, Indonesia masih belum bisa memaksimalkan penerimaan pajak dan meningkatkan tax ratio Indonesia. Pengampunan pajak seakan menjadi jalan pintas dari pemerintah untuk tujuan yang masih harus dibuktikan, antara menambal pendapatan negara ataupun menjadikan pengampunan pajak sebagai agenda reformasi pajak. Berdasarkan penelitian Ragimun (2014), program tax amnesty dapat dilakukan di Indonesia, namun pelaksanaannya ditunda, dikarenakan payung hukum atas pelaksanaan tax amnesty dan keterbukaan informasi yang belum jelas. 
Indonesia merupakan salah satu negara yang masih menjadikan pajak sebagai tumpuan utama atas pendapatan negara. Pentingnya peran pajak dalam pembangunan dan pemenuhan kebutuhan, menuntut pemerintah untuk mencari strategi terbaik di bidang fiskal. Permasalahan klasik dari perpajakan Indonesia, yaitu:

\section{a. Tax Ratio}

Indonesia hanya mampu memiliki $11-13 \%$ tax ratio dari GDP. Kualifikasi yang cukup jauh jika dibandingkan negara di ASEAN terlebih jika disejajarkan dengan negara berkembang lainnya.

b. Kepatuhan Wajib Pajak

Dalam sistem pemungutan pajak menganut sistem self assessment. Sistem self assessment, wajib pajak diberi kepercayaan untuk menghitung, memperhitungkan, menyetor, dan melaporkan sendiri besarnya pajak yang terutang sesuai dengan ketentuan peraturan perundang-undangan perpajakan. Sebagai konsekuensi pemberian kepercayaan tersebut, wajib pajak wajib menyampaikan surat pemberitahuan berikut keterangan. Kepatuhan tidak akan berjalan tanpa adanya kesadaran dari para waijb pajak, meningkatkan kepatuhan seharusnya satu kesatuan dengan peningkatan kesadaran wajib pajak. Dibutuhkan pembaruan dalam peningkatan kepatuhan dan kesadaran pajak di Indonesia, tidak bisa hanya dibebankan kepada Direktorat Jenderal Pajak. Konsep alat pemaksa harus dapat dihadirkan dalam agenda reformasi pajak.

c. Penegakan Hukum

Kekayaan itu sifatnya mencari keamanan, masalah pengemplang pajak menjadi masalah klasik di setiap negara. Pembenahan dalam hukum menjadi agenda reformasi pajak sebagai suatu cara untuk mempersiapkan kekurangan di dalam aturan yang sudah ada, seperti dalam Undang-Undang Ketentuan Umum dan Tata Cara Perpajakan, UndangUndang Pajak Penghasilan, UndangUndang Pajak Pertambahan Nilai Barang dan Jasa dan Pajak Penjualan atas Barang Mewah, Undang-Undang Pajak Bumi dan Bangunan, UndangUndang Bea Perolehan Hak Atas Tanah dan/atau Bangunan, UndangUndang Penagihan Pajak dan Surat Paksa.

d. Penghindaran Pajak (Tax Avoidance)

Wajib pajak yang tidak patuh membayar pajak disebabkan oleh penegakan hukum yang tidak konsisten. Hukuman yang ringan dan alat paksa yang belum memadai hanya akan membuat para penghindar pajak semakin banyak di negara berkembang. Becker dan Allingham \& Sandmo, menyatakan bahwa pelarian pajak yang sangat ambisius yang terdapat di negara berkembang, hanya dapat dikurangi dengan menerapkan hukuman yang tinggi, dan untuk memperkuat hal tersebut, desain kebijakan pemerintah 
diupayakan untuk memperkuat optimalisasi penggunaan hukuman secara maksimal.

\section{Konstitusionalitas dan Pertimbangan Mahkamah Konstitusi}

Terdapat tujuh alasan yang menjadi pertimbangan Mahkamah Konstitusi dalam memutus Putusan Nomor 63/PUU-XIV/2016. Keadaan ekonomi di tahun 2008 yang masih belum pulih sepenuhnya menjadi pertimbangan. Mahkamah Konstitusi mempertimbangkan bahwa pemberlakuan Undang-Undang Pengampunan Pajak di kemudian hari akan memberi keadilan kepada masyarakat dengan dimilikinya data baru terkait wajib pajak. Hal ini dikarenakan bahwa Undang-Undang Pengampunan Pajak memiliki tujuan untuk merepatriasi dana di luar negeri, meningkatkan basis perpajakan nasional dan untuk meningkatkan penerimaan pajak.

Menganalisis pengujian undang-undang tentang pengampunan pajak didasari oleh tiga landasan, yakni: landasan filosofis, landasan hukum, serta landasan praktis. Hal inipun sesuai dengan teori yang dikemukakan oleh Radbruch yang telah diterima secara luas bahwa cita hukum didasari oleh tiga nilai, yaitu keadilan, kepastian, dan kemanfaatan. Dalam landasan filosofis, Pancasila sebagai dasar negara Indonesia menjadi pijakan utama dan pertama dalam mendasarkan segala hukum yang berlaku. Pancasila menjadi dasar arah tujuan negara.

Tujuan negara telah dijabarkan dalam pembukaan UUD NRI 1945, untuk melindungi segenap bangsa Indonesia dan seluruh tumpah darah Indonesia serta untuk memajukan kesejahteraan umum, mencerdaskan kehidupan bangsa, dan ikut melaksanakan ketertiban dunia yang berdasarkan kemerdekaan, perdamaian abadi, dan keadilan sosial.

Pada penjelasan umum Undang-Undang Pengampunan Pajak termaktub makna filosofis yang menjadi tujuan utama dari undang-undang ini yakni untuk mendistribusikan pembangunan nasional secara merata tanpa pembeda atas penerimaan negara yang dalam hal ini penerimaan yang berasal dari pajak. Pembangunan nasional yang dilakukan oleh pemerintah ditujukan untuk meningkatkan kesejahteraan masyarakat (Waluyo \& Ilyas , 2011). Keberhasilan pembangunan nasional akan memengaruhi pertumbuhan ekonomi nasional yang berdampak terhadap pemenuhan dan realisasi tujuan negara.

Implikasi penerapan pengampunan pajak secara jangka pendek, akan berdampak pada perbaikan kondisi ekonomi yang saat ini sedang tidak stabil dengan penambahan dana pada pendapatan negara. Kemudian secara jangka panjang diharapkan dapat mengimplementasikan reformasi pajak secara nyata, dengan meningkatkan angka rasio pajak. Kedua hal ini menjadi kekuatan Undang-Undang Pengampunan Pajak untuk menjadi salah satu cara yang dipilih oleh pemerintah dalam bidang fiskal untuk mempercepat pembangunan dan mengurangi pengangguran, kemiskinan, dan kesenjangan.

Landasan hukum terkait Undang-Undang Pengampunan Pajak didasari pada Pasal 5 ayat (1), Pasal 20, dan Pasal 23A UUD NRI 1945. Para pemohon dalam permohonannya mendalilkan bahwa undang-undang tersebut bertentangan dengan Pasal 1 ayat (3), Pasal 23A, Pasal 27 ayat (1), dan Pasal 28F UUD NRI 1945. Pada Bab VII tentang Hal Keuangan Pasal 23A UUD NRI 1945 tertulis bahwa pajak dan pungutan lain yang bersifat memaksa untuk keperluan negara diatur 
dengan undang-undang. Pengampunan pajak dinilai bertentangan dengan pasal tersebut, term "bersifat memaksa" menjadi alasan bahwa makna tersebut bertentangan dengan pengampunan pajak yang dimaknai sebagai ampunan terhadap wajib pajak yang melanggar.

Berdasarkan kamus besar bahasa Indonesia kata memaksa berarti meminta dengan paksa atau mendesak (berbuat) dengan kekerasan. Sedangkan pengampunan dalam Pasal 1 angka 1 dijelaskan sebagai penghapusan pajak terhutang dan meniadakan sanksi. Artinya ada pergeseran makna dari awalnya bersifat memaksa kemudian menjadi tidak. Dari hemat penulis, bahwa term "pengampunan" merupakan konsekuensi dari sebuah pungutan pajak atau pungutan lainnya yang bersifat memaksa. Karena memaksa inilah maka terdapat pengampunan terhadap mereka yang melanggar. Kedua term ini tidak dilihat sebagai suatu makna yang terpisah. Apabila ada pungutan lain yang tidak bersifat memaksa maka tidak ada arti pengampunan. Pengampunan adalah konsekuensi logis dari keadaan memaksa.

Landasan praktis didasari oleh tuntunan ekonomi global mengharuskan Indonesia bertindak untuk memperkuat politik anggaran. Dalam politik anggaran pada kebijakan APBN seyogianya tidak melulu berfokus pada jumlahnya, namun juga bagaimana struktur pendapatan dan pengeluaran. Defisit anggaran atau penerimaan negara yang tidak sesuai dengan target menjadi pekerjaan rumah yang masih harus dibenahi oleh pemerintahan.

Menurut Nasution, terdapat empat cara untuk menutupi defisit pada APBN, antara lain: hibah luar negeri, pinjaman luar negeri, mencetak uang, dan penjualan aset negara. Hal ini terjadi karena politik anggaran Indonesia yang tidak berpijak pada konstitusi. Secara jangka pendek tax amnesty adalah salah satu cara untuk menambah penerimaan negara di sektor pajak.

Pengampunan pajak yang dinilai sebagai alat untuk berkompromi dengan penjahat, berdasarkan Pasal 20 s.d 23 Undang-Undang Pengampunan Pajak yang menegaskan bahwa terdapat pemberian perlindungan pada data dan informasi atas apa yang disampaikan dari para wajib pajak. Hal ini menjadi dasar problematika bahwa Undang-Undang Pengampunan Pajak menjadi legalitas dari perolehan uang hasil kejahatan.

Ditelaah lebih jauh, data dan informasi pengampunan pajak tidak dapat menjadi dasar penyelidikan, penyidikan, dan penuntutan pidana terhadap wajib pajak. Namun, apabila nantinya seorang wajib pajak oleh lembaga yang berwenang diduga terlibat dalam tindak pidana, pengampunan pajak tidak diartikan negara menerima kejahatannya. Hal ini merupakan sebuah domain yang berbeda, tindak pidana asal akan tetap melekat jika di kemudian hari ditemukan bukti yang kuat, bahwa benar jika sumber penghasilannya dari hasil kejahatan. Akan tetapi, bukti tersebut tidak bisa berasal dari data dan informasi pengampunan pajak.

Hal ini sekaligus menjawab dalil pemohon terkait Undang-Undang Pengampunan Pajak yang bertentangan dengan pasal hak asasi manusia di dalam UUD NRI 1945, terlebih pada hak untuk mendapatkan informasi atau prinsip keterbukaan informasi. Undang-Undang Pengampunan Pajak melindungi hak asasi para wajib pajak tanpa pembeda, mereka para wajib pajak yang mendapatkan penghasilan secara wajar akan dilindungi begitupun dengan para wajib pajak yang memperoleh hasil kekayaan 
dari kegiatan usaha yang melanggar juga tetap dilindungi sebagai bagian dari wajib pajak.

Menurut Isra (2016), konstruksi berfikir Mahkamah Konstitusi dalam menafsirkan kepastian hukum dalam pembentukan undangundang melalui pengujian terdapat empat hal yang mendasari, antara lain:

a. Bentuk pengaturan, apakah hukum tersebut telah dituangkan dalam bentuk hukum yang tepat;

b. Perumusan norma, apakah norma undang-undang yang dibentuk telah disusun secara jelas dan tidak multitafsir, dan apakah norma tidak diubah setiap saat sehingga menimbulkan kebingungan;

c. Konsistensi antar norma (vertikal maupun horizontal), apakah norma yang dibentuk telah sesuai dengan peraturan yang lebih tinggi dan tidak bertabrakan dengan norma yang setingkat dengannya; dan

d. Keberlakuannya. Norma hukum harus diberlakukan secara prospektif dan diberlakukan sesuai secara proporsional.

Pemerintah menghadapi masalah keuangan dan pembangunan secara sistemik serta dilematis. Pengampunan pajak adalah second best effort di luar penegakan hukum normal. Apabila pemerintah hanya fokus pada penegakan hukum di bidang perpajakan, maka yang saat ini nyata dialami, tidak tercapainya target pendapatan negara, karena data wajib pajak yang belum meningkat dan dana besar yang ditempatkan di luar negeri. Pengampunan pajak merupakan pilihan pemerintah yang dilakukan untuk tujuan yang lebih besar.

Substansi permohonan yang diajukan oleh para pemohon dengan pasal-pasal dalam undangundang terkait yang dinyatakan inkonstitusional dinilai tidak beralasan menurut hukum. Pasal 11 jo. Pasal 19 ayat (1) dan (2), pembebasan sanksi administrasi dan sanksi pidana perpajakan merupakan konsekuensi dari pengertian pengampunan pajak dalam Undang-Undang Pengampunan pajak. Pasal 20 tidak bertentangan dengan konstitusi sepanjang diartikan tidak termasuk tindak pidana lain, di luar pidana di bidang perpajakan.

\section{B. Implikasi Hukum dan Legalitas Hukum Amnesti Pajak terhadap Tingkat Kepatuhan Wajib Pajak di Indonesia}

Pada 14 Desember 2016, Mahkamah Konstitusi memutuskan atas pokok permohonan tidak dapat diterima. Putusan ini menjadi dasar berlakunya kebijakan pengampunan pajak yang dinilai mencederai rasa keadilan dan menjadi legitimasi perilaku jahat para masyarakat yang tidak patuh membayar pajak. Berdasarkan Undang-Undang Pengampunan Pajak, kebijakan ini akan berakhir pada tanggal 31 Maret 2017. Realisasi amnesti pajak sebesar 135 triliun dengan komposisi 114 triliun dari pembayaran tebusan, 18.6 triliun dari pembayaran tunggakan dan 1.75 triliun dari pembayaran bukper. Kemudian, realisasi amnesti pajak berdasarkan surat pernyataan harta 4.855 triliun dengan komposisi deklarasi dalam negeri sebesar 3.676 triliun, deklarasi luar negeri sebesar 1.031 triliun dan repatriasi sebesar 147 triliun.

Pencapaian ini menjadi keberhasilan tertinggi bagi sejarah pengampunan pajak di 
Indonesia. Begitupun apabila dibandingkan dengan negara lain, Indonesia menjadi negara dengan pencapaian terbaik dalam hal amnesti pajak. Italia sebagai pemegang rekor presentase dana repatriasi terbesar di dunia atas pengampunan pajak sebesar $3.5 \%$ dari PDB atau sekitar 80 miliar euro di tahun 2009. Serta apabila dibandingkan dengan pemegang rekor presentase uang tebusan terbesar di dunia yang dipegang oleh Argentina sebesar 1.5\% dari PDB, senyatanya masih jauh dari Indonesia. Kemudian, dana deklarasi Indonesia tertinggi di dunia dengan capaian 4.855 triliun yang mana di posisi kedua ditempati oleh Italia sebesar 1.179 triliun di tahun 2009.

Kebijakan amnesti pajak berhasil memengaruhi $\mathrm{PPh}$ dan PPN yang tumbuh dengan positif. Berdasarkan laporan dari Dirjen Pajak, realisasi penerimaan pajak meningkat $16.98 \%$ dari target APBN. Namun demikian, keberhasilan tax amnesty secara keseluruhan tidak diikuti dengan satuan komponen komposisi pengampunan pajak. Keberhasilan deklarasi tidak diikuti dengan keberhasilan repatriasi yang hanya di angka 147 triliun sedangkan target awal adalah 1.000 triliun.

Berdasarkan konsepsi repatriasi, kegiatan masuknya dana di luar Indonesia akan menambah subjek dan objek pajak baru di Indonesia. Sedangkan yang terjadi saat ini adalah repatriasi hanya berhasil dilakukan $15 \%$ dari target. Deklarasi dalam negeri menjadi pemasukan utama dalam program pengampunan pajak era pemerintahan saat ini. Angka ini menjadi catatan penting yang diartikan bahwa tingkat kepercayaan para wajib pajak yang menaruh harta kekayaannya di luar negeri masih rendah terhadap pemerintah dan sistem hukum di Indonesia. Pengampunan pajak akan memiliki implikasi besar terhadap peningkatan subjek dan objek pajak jika diawali dari tingginya angka repatriasi.

Instrumen pengampunan pajak belum dapat menarik triliunan uang investasi para subjek pajak di luar negeri untuk masuk kembali ke Indonesia. Akan tetapi, pengampunan pajak ini justru digunakan oleh para wajib pajak di dalam negeri yang di dalamnya masih banyak unsur kegiatan usaha yang berasal dari kelas menengah dan kecil.

Amnesti pajak adalah pintu masuk dimulainya reformasi pajak yang sesungguhnya. Masuknya uang puluhan triliun rupiah harus dikelola secara profesional, baik infrastrukturnya maupun pejabat berwenang. Terdapat dua hal yang harus terus diperkuat, sistem pengelolahan keuangan (instrumen investasi) dan pembenahan infrastruktur perpajakan. Pada tahap pemungutan pajak Dirjen Pajak menjadi institusi utama yang berperan, namun secara domain ketika menganalisis banyaknya dana yang terkumpul dan kemudian apa yang pemerintah lakukan terhadap dana tersebut, Dirjen Pajak memang tidak lagi berada pada wilayah tersebut. Akan tetapi, pemerintah seharusnya sudah menyiapkan berbagai instrumen investasi.

Pembenahan infrastruktur perpajakan sangat luas salah satunya adalah pembenahan dalam birokrasi. Karakteristik lembaga birokrasi dicirikan tidak adaptif, sehingga pekerjaan rumah yang besar adalah merubah karakter dan mempermudah para wajib pajak untuk merealisasikan kesadaran atas kepatuhan membayar pajak. Kemudian, pembenahan dan mengevaluasi berbagai aturan terkait pajak, serta memperbarui dengan berkala data dan informasi wajib pajak untuk meningkatkan rasio pajak berikutnya. Di samping itu, untuk membangun 
kepatuhan sukarela untuk membayar pajak setelah tax amnesty diharuskan adanya transparansi penggunaan uang pajak (anggaran) serta alokasinya yang tepat sasaran dan berkeadilan (Ngadiman \& Huslin, 2015).

\section{KESIMPULAN}

Permohonan uji materiil yang dilakukan atas Undang-Undang Nomor 11 Tahun 2016 tentang Pengampunan Pajak adalah hak konstitusionalitas dari setiap warga negara. Putusan Mahkamah Konstitusi yang memutuskan bahwa pokok permohonan tidak dapat diterima telah memberikan implikasi hukum atas berlakunya kebijakan pengampunan pajak dengan kepastian hukum.

1. Mahkamah dalam mempertimbangkan kepastian hukum pengujian undangundang berdasarkan pada bentuk pengaturan, perumusan norma, konsistensi antar norma (vertikal maupun horizontal), dan keberlakuannya secara prospektif dan proporsional. Pertimbangan dalam keadilan dan kemanfaat hukum ditegaskan dalam argumentasi para saksi ahli dan kondisi sosial masyarakat Indonesia. Pengampunan pajak memiliki dua perspektif kegunaan, jangka pendek sebagai penambahan penerimaan pendapatan negara, yang mana kebijakan ini akan memengaruhi kesejahteraan masyarakat. Kemudian, jangka panjang sebagai bagian agenda dari reformasi pajak, yang akan berdampak kepada pembangunan nasional.

2. Implikasi hukum dari putusan Mahkamah Konstitusi atas pengujian UndangUndang Pengampunan Pajak dapat terlihat dari pencapaian berjalannya kebijakan pengampunan pajak. Dari tiga unsur pengampunan pajak, terdapat satu unsur yakni repatriasi yang tidak sesuai dengan target, yang mana hal tersebut justru memengaruhi penambahan subjek dan objek pajak baru. Kepatuhan wajib pajak dapat dianalisis dari keberhasilan angka deklarasi yang melampaui target. Hal ini memberi dampak penambahan informasi baru terhadap harta kekayaan para wajib pajak.

\section{DAFTAR ACUAN}

Amiruddin \& Asikin, Z. (2012). Pengantar metode penelitian hukum. Jakarta: Rajawali Pers.

Asshidiqie, J. (2010). Pengantar ilmu hukum tata negara. Jakarta: Rajagrafindo Persada.

Direktorat Jenderal Pajak Kementrian Keuangan [Dirjen Pajak]. (2016). Diakses dari http:// www.pajak.go.id/content/article/refleksitingkat-kepatuhan-wajib-pajak.

DPR RI. (2016). Naskah akademik Undang-Undang Nomor 11 Tahun 2016 tentang Pengampunan Pajak. Jakarta: Sekretariat Jenderal DPR RI.

Hartono, C.F.G.S. (1994). Penelitian hukum di Indonesia pada akhir abad ke-20. Bandung: Alumni.

Isra, S. (2016). Keterangan Ahli PUU Nomor 11 Tahun 2016 tentang Pengampunan Pajak, lihat salinan Putusan Nomor 63/PUU-XIV/2016. Jakarta: MK RI.

Kementerian Keuangan RI [Kemenkeu]. (tt). Diakses dari https://www.kemenkeu.go.id/Berita/ realisasi-pendapatan-negara-tahun-2014capai-rp15372-triliun. 
Kementerian Keuangan RI [Kemenkeu]. (tt). Diakses dari https://www.kemenkeu.go.id/SP/realisasipelaksanaan-apbnp-tahun-2015.

Luitel, H.S. (2014). Is tax amnesty a good policy? London: Lexington Books.

Mardiasmo. (2011). Perpajakan. Yogyakarta: Penerbit Andi.

Nar, M. (2015). The effects of behavioral economics on tax amnesty. International Journal of Economics and Financial Issues, 5(2), 580589.

Ngadiman \& Huslin, D. (2015). Pengaruh sunset policy, tax amnesty, \& sanksi pajak terhadap kepatuhan wajib pajak (Studi empiris di Kantor Pelayanan Pajak Pratama Jakarta Kembangan). Jurnal Akuntansi, 19(2), 225-241.

No name. (2016). Kinerja penerimaan pajak jangka panjang. Inside Tax, Edisi 36, 34-35.

Prastowo, Y. (2016). Repatriasi aset akan sulit dijaring mayoritas aset di dalam negeri. Harian Kompas, 17.

Ragimun. (2014). Analisis implementasi pengampunan pajak (Tax amnesty) di Indonesia. Jakarta: Badan Kebijakan Fiskal Kementerian Keuangan Republik Indonesia.

Rahayu, S.K. (2010). Perpajakan Indonesia: Konsep dan aspek formal. Yogyakarta: Graha Ilmu.

Setyaningsih, T. (2016). Mengapa wajib pajak mengikuti tax amnesty. Jurnal Ekonomi dan Keuangan, 2.

Soekanto, S., \& Mamuji, S. (2006). Penelitian hukum normatif, suatu tinjauan singkat. Jakarta: Rajagrafindo Persada.

Waluyo \& Ilyas, W.B. (2011). Perpajakan Indonesia. Buku 1 Edisi 10. Jakarta: Salemba Empat. 